\title{
Floc contribution on spawning performance of blue shrimp Litopenaeus stylirostris
}

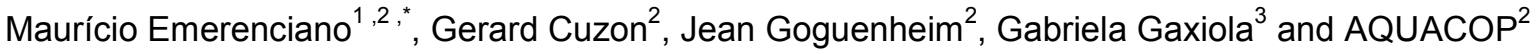 \\ ${ }^{1}$ Posgrado en Ciencias del Mar y Limnología, Universidad Nacional Autónoma de México (UNAM), Unidad \\ Multidisciplinaria de Docencia e Investigación (UMDI), Sisal, Yucatán, Mexico \\ ${ }^{2}$ Ifremer-COP (Institut français de recherche pour l'exploitation de la mer, Centre Océanologique du Pacifique), \\ Taravao, Tahiti, French Polynesia \\ 3 Facultad de Ciencias (UNAM), Unidad Multidisciplinaria de Docencia e Investigación (UMDI), Sisal, Yucatán, \\ Mexico \\ *: Corresponding author : Maurício Emerenciano, email address : mauricioemerenciano@hotmail.com
}

\begin{abstract}
:
The floc system has been successfully applied for shrimp grow-out, but little is known about floc contribution on reproductive performance. In a 30-day trial, spawning performance of broodstock was evaluated in floc and earthen ponds. Floc spawners achieved better results $(P<0.05)$ compared with pond spawners in terms of number of spawns per ablated female (2.9 vs. 1.3), spawns per spawning female (3.6 vs. 2.4) and number of consecutive maturation (average of 3.6 times compared with 2.5 times in ponds females). Latency period was lower for floc spawners $(7.4$ days) than pond spawners $(10.7$ days $)(P<0.05)$. The percentage of females that spawned at least once were higher in floc $(77.1 \%)$ when compared with pond spawners $(53.8 \%)(P<0.05)$. Number of eggs per spawn per $g$ of spawner's body weight and female mortality presented no significant differences between treatments $(P>0.05)$. Biochemical analysis as a nutritional status indicator showed no difference between treatments in hepatopancreas $(P>0.05)$, with the exception of lowest values of acylglycerides and acylglycerides/total soluble protein ratio in floc females ovary $(P<0.05)$. Results evidenced better overall spawning performance for $L$. stylirostris broodstock produced under floc condition than in earthen ponds.
\end{abstract}

Keywords : floc ; Litopenaeus stylirostris ; Reproduction ; broodstock

\section{Introduction}

The term 'floc' is a designation that can be defined as flocculation of organic matter present in the medium resulting in a high concentration of particulate biomass, and could also represent a culture system called 'moulinettes' (Aquacop 1975; Cuzon, Lawrence, Gaxiola, Rosas \& Guillaume 2004). The latter is described as a water column in constant movement with strong aeration. Floc system was developed in early 70's at Ifremer-COP with different peneid species including Penaeus monodon, Fenneropenaeus merguiensis, $L$. vannamei and L. stylirostris (Aquacop 1975; Sohier 1986). Such culture system was compared with an 'external rumen' (Cuzon et al. 2004), but now applied for shrimp. This concept illustrated a complex interaction between organic matter, physical substrate and large range of microorganisms such as bacteria, protozoa, rotifers, nematodes and others microorganisms, providing a food source for one major species (Ray, Seaborn, Leffler, Wilde, Lawson \& Browdy 2010). In 1980, the programme 'Ecotron' was initiated by Ifremer to better understand the floc system. Several studies enabled a comprehensive approach to the 'floc' and explained interrelationships between different compartments such as water and bacteria, as well as shrimp nutritional physiology.

Currently, other researchers proposed alternate appellation, such as 'zero or limited water 
exchange' (Wasielesky, Atwood, Stokes \& Browdy 2006; Samocha, Patnaik, Speed, Ali, Burger, Almeida, Ayub, Harisanto, Horowitz \& Brock 2007; Ballester, Abreu, Cavalli, Emerenciano, Abreu \& Wasielesky 2010), suspended-growth systems (Hargreaves 2006) and more recently 'biofloc technology' (Azim \& Little 2008; De Schryver, Crab, Defoirdt, Boon \& Verstraete 2008; Avnimelech 2009). In early 70's, Ralston Purina developed a system based on nitrifying bacteria while keeping shrimp in total darkness. In connection with Aquacop, such system was applied to L. stylirostris and L. vannamei both in Crystal River (USA) and Tahiti (Rosenberry 2010), and led to considerations on benefits of floc for shrimp culture.

Originally conceptualized in small volumes $\left(12 \mathrm{~m}^{3}\right)$, biofloc system was extended to outdoors tanks $\left(30 \mathrm{~m}^{3}\right.$ circular tanks or $1000 \mathrm{~m}^{2}$ rectangular concrete tanks). In 1988, a world record in production (20-25 $\mathrm{mt} \mathrm{ha}^{-1}$ year $^{-1}$ ) was obtained by Sopomer farm in Tahiti using floc in concrete tanks (Garen \& Aquacop 1993; Rosenberry 2010). Currently, floc system is being applied successfully in large-scale shrimp farming in Asia and Latin America (Burford, Thompson, McIntosh, Bauman \& Pearson 2004; Taw 2010), although knowledge on bacteria and phytoplankton interaction-control in large-scale shrimp ponds remains scarce. The main problems detected are fluctuations in $\mathrm{pH}$, alkalinity and nitrogen compounds (Rosenberry 2010).

Some authors suggest to stock microalgae before floc development in small-scale experiments (Emerenciano, Wasielesky, Soares, Ballester, Cavalli \& Izeppi 2007; Ballester et al. 2010) aiming to maintain water quality, provide food and guarantee a source of C:N, as algae growth is followed by bacterial growth (Cole 1982; Williams 2000; Hargreaves 2006). On the other hand, it is possible to leave the medium with its own strains, although phytoplankton bloom could be delayed. Initiating a floc in outdoor conditions remains a rule of thumb. As a general guide, the three considerations would be (i) a minimum of $300 \mathrm{~g}$ of shrimp biomass $\mathrm{m}^{-2}$ achieved at juvenile stage; (ii) a regular input of dry feed with low protein content (Azim \& Little 2008) or application of an external carbon source (Avnimelech 2009); and (iii) limited or zero water exchange.

The potential to introduce disease into shrimp facilities, through infected wild broodstock and vertical transmission of pathogen, has placed con- siderable interest on penaeid breeding programmes (Ibarra, Racotta, Arcos \& Palacios 2007) and production of biosecure closed-life cycle broodstock (Regunathan 2008). Penaeid breeding programmes were frequently associated with rapid growth and disease resistance as well as the enhancement of reproductive performance (Goyard, Patrois, Peignon, Vanaa, Dufour, Viallon \& Bedier 2002; Racotta, Palacios \& Ibarra 2003; Gitterle, Salte, Gjerde, Cock, Johansen, Salazar, Lozano \& Rye 2005). Domestication of broodstock is a rule in shrimp industry to control production plan of successive generations (Coman, Arnold, Callaghan \& Preston 2007). However, nutritional problems in domesticated broodstock remain unresolved (Wouters, Lavens, Nieto \& Sorgeloos 2001a), and alternatives should be evaluated. Floc as a benefit for shrimp broodstock is still under investigation (Emerenciano, Cuzon \& Gaxiola 2011), and its importance on the zootechnical parameters, and relationships between nutrition and different environmental conditions remain to be validated. The aim of this study was to evaluate floc contribution on spawning performance of blue shrimp, L. stylirostris, as a preliminary approach of floc application in shrimp broodstock.

\section{Materials and methods}

\section{Experimental design and culture conditions}

This work was carried out at Ifremer-COP, Tahiti, French Polynesia, and data were derived from three trials of each broodstock source in floc and earthen ponds.

Broodstock production protocol was based on a stock of $L$. stylirostris juveniles $(\sim 1 \mathrm{~g})$ raised in $400-700 \mathrm{~m}^{2}$ earthen ponds (1-1.2 $\mathrm{m}$ depth) at a density of 4 shrimp $\mathrm{m}^{-2}$ with $5-20 \%$ daily water exchange rate. Shrimps were fed commercial feed ( $40 \% \mathrm{CP}$ ) at $3-10 \%$ shrimp biomass twice a day at 08:00 and 16:00 hours. After 4-5 months at 25-30 g, two different management strategies were applied: (i) change of pond stocked at 2 shrimp $\mathrm{m}^{-2}$ with a new phytoplankton bloom until transfer to maturation room and (ii) stock in floc system based on $30 \mathrm{~m}^{3}$ circular fibre glass tanks called 'moulinettes' (Cuzon et al. 2004) at 15 shrimp $\mathrm{m}^{-2}$ until transfer to maturation room.

Protocol in floc was based on water, vigorously aerated using a finely perforated ring of PVC tube (32 $\mathrm{mm} ; 40 \mathrm{~cm}$ diameter) positioned in the centre 
of the tank. Water exchange was limited $(<5 \%$ flow rate), and central waste evacuation was performed daily to prevent sludge accumulation. The tanks were totally covered for an approximately $90 \%$ reduction in light by shade cloth to control excessive phytoplankton bloom. C:N ratio was based only on $\mathrm{C}: \mathrm{N}$ content present in commercial feed (8:1).

After 4-5 months since stocking of PL, animals of both sources were provided a ration of fresh food consisting of frozen squid, once a week, at $2 \%$ biomass (based on dry matter) in addition to commercial feed. A summary of experimental procedure is given in Fig. 1.

\section{Reproductive performance}

Each reproductive trial (30-day) were performed in eight $4 \mathrm{~m}$ diameter fibre glass maturation tanks, four per origin (floc or pond), where one tank was used to stock males and the remaining three for females. The water exchange was carried out with flow-through during summer or recirculation system during winter to keep temperature at $26.5 \pm 1.6$. Batches of 22-32 females and 50-60 males from each source were stocked at a density of 2.5-3.5 and 5.5-6.6 shrimp $\mathrm{m}^{-2}$, for female and male, respectively. Animals were fed ad libitum three times per day at 08:00, 11:00 and 16:00 hours, with commercial feed, frozen squid and frozen mussels.

Before the start of the trial, the shrimps were acclimated for 1 week, and each female was weighed and unilaterally eyestalk ablated to enhance gonadal development and tagged with an eye ring. The spawners with fully developed ovary (ready-to-spawn) was sourced out daily, artificially inseminated with male spermatophores from the same source (manually eject by applying gentle pressure to the base of the genital pore, Arce, Moss \& Argue 1999) and transferred to a $180 \mathrm{~L}$ conical-bottom spawning tank containing aerated seawater. The number of eggs was estimated from four replicates of $1.0 \mathrm{~mL}$ samples, and collected after homogenization of spawning tanks. Reproductive performance was evaluated in terms of female mortality (\%), latency period (interval in days between eyestalk ablation and first spawn), number of eggs (per spawn per $g$ of spawner's body weight), number of consecutive maturations per female, percentage of female that spawn at least once (\%), number of spawns per ablated female, number of spawns per spawning female, number of spawns per female per month and cumulative spawning rate $(\%)$.

\section{Biochemical analysis}

After ablation, hepatopancreas (HP) and ovaries (OV) were collected from twelve ready-to-spawn females from each treatment. HP and OV were removed through an incision on the back of the cephalothorax and dorsal region of the entire abdomen length, respectively. Samples were weighed, placed in $1.5 \mathrm{~mL}$ Eppendorf tubes, immediately frozen in liquid nitrogen and preserved at $-80^{\circ} \mathrm{C}$. Subsequently, samples were freeze-dried and re-stocked at $-80^{\circ} \mathrm{C}$ for further analysis.

Changes in metabolite levels of acylglycerides (AG), cholesterol and total soluble proteins (TSP) in $\mathrm{HP}$ and $\mathrm{OV}$ were used as indicators for nutritional status of female broodstock. AG/TPS (AG: TSP) and AG/cholesterol ratio (AG:C) as a condition index were calculated using metabolites data (Mourente \& Rodríguez 1997; Palacios, Ibarra, Ramirez, Portillo \& Racotta 1998; Anger 2001). $\mathrm{HP}$ and $\mathrm{OV}$ were homogenized in $500 \mathrm{ml}$ of distilled water for $2 \mathrm{~min}$. Aliquots of $20 \mu \mathrm{L}$ were

Figure 1 Summary of experimental procedure carried out for growout phase (floc or earthen pond; total of 10-12 month) and maturation phase (30 days).

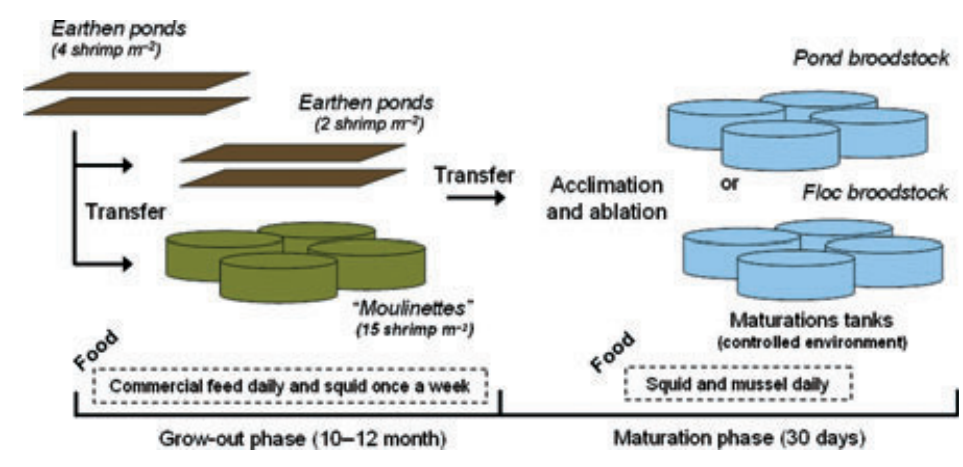


taken to determine $\mathrm{AG}$ and cholesterol with $200 \mu \mathrm{L}$ of reactive solution (Kits Elitech Diagnostics, Sees, France; cat. TGML-0427 and cat. CHSL0507, respectively). The rest of the sample was centrifuged at $2500 \mathrm{rpm}$ for $3 \mathrm{~min}$ at $4^{\circ} \mathrm{C}$, and $20 \mu \mathrm{L}$ of the supernatant was collected in Eppendorf tubes to determine TPS with $200 \mu \mathrm{L}$ of Bradford reactive solution (Bradford 1974). Solutions were transferred to microplates in triplicate and incubated in an oven for 7,6 and $5 \mathrm{~min}$ in 37 , 37 and $24^{\circ} \mathrm{C}$ for AG, cholesterol and TPS, respectively. Immediately after, samples were read in an ELISA reader (Bio-Rad Laboratories, Richmond, CA, USA) at $500 \mathrm{~nm}$ and $595 \mathrm{~nm}$ for total protein. A blank was considered with distilled water and the final concentrations $\left(\mathrm{mg} \mathrm{g}^{-1}\right)$ were calculated from a calibration curve, in which the standard was the substrate as reagent in the kit.

\section{Statistical analysis}

For reproductive performance and biochemical analysis, Student's t-test was applied to find the differences among the treatments when data were homogeneous and normality distributed (Sokal \& Rohlf 1995). Percentage data were calculated using Chi-Square method, and differences were considered significant at $P<0.05$ (Zar 1984).

\section{Results}

The results of spawning performance are given in Table 1. Number of egg per spawn per $g$ of spawner's body weight and female mortality presented no significant differences between treatments $(P>0.05)$. Floc spawners showed better reproductive performance $(P<0.05)$ in terms of number of spawns (per ablated female and per spawning female) and number of consecutive maturation compared with spawners from ponds $(2.9,3.6$ and 3.6 for floc and 1.3, 2.4 and 2.5 for earthen pond, respectively). Latency period was shorter for floc spawners (7.4 days) than pond spawners (10.7 days) $(P<0.05)$. The percentage of females that spawned at least once were higher in floc (77.1\%) when compared with pond ones $(53.8 \%)$ $(P<0.05)$. Cumulative spawning rate $(\%)$ from 3rd to 10th day indicated that females from floc had a slightly higher rate than females from ponds, and then both sources showed the same trend until 30th day (Fig. 2). Number of spawns per female per month was similar during the first 2 days (Fig. 3). From the 3rd day, a difference in performance was observed that was maintained until day 30 (2-3 spawns per female per month in floc vs. $<1$ in pond females). Floc spawners showed a quicker response to ablation by presenting a higher rhythm of spawn in a shorter period of time (Fig. 2 and 3), as well as achieved a higher spawn order compared with pond ones (Fig. 4).

The biochemical data (Table 2) from hepatopancreas showed no significant differences for all variables between floc and earthen pond spawners $(P>0.05)$. On the other hand, in ovary, AG (64.2 $\mathrm{mg} \mathrm{g}^{-1}$ ) and AG:TPS (0.6) were higher for pond spawners than for floc spawners (AG: $42.2 \mathrm{mg} \mathrm{g}^{-1}$ and AG:TPS: 0.4$)(P<0.05)$.

\section{Discussion}

\section{Reproductive performance}

In a shrimp hatchery, a large percentage of the females in any production cycle spawn only once

Table 1 Spawning parameters (means $\pm \mathrm{SD}$ ) of L. stylirostris broodstock from floc system and earthern pond during a period of 30 days

\begin{tabular}{|c|c|c|c|}
\hline & Pond & Floc & Significance level \\
\hline \multicolumn{4}{|l|}{ Reproductive parameters } \\
\hline Weight female $(\mathrm{g})$ & $40.5 \pm 4.3^{\mathrm{a}}$ & $53.6 \pm 6.5^{\mathrm{b}}$ & $* * *$ \\
\hline Weight male $(\mathrm{g})$ & $35.4 \pm 6.0^{\mathrm{a}}$ & $50.5 \pm 3.8^{b}$ & $* * *$ \\
\hline Number of egg per spawn $\left(\times 10^{3}\right)$ per $g$ of spawner's body weight & $3.3 \pm 1.1$ & $3.9 \pm 1.9$ & ns \\
\hline Female mortality $(\%)$ & $69.9 \pm 29.8$ & $68.0 \pm 15.7$ & ns \\
\hline Number of spawn/ablated female & $1.3 \pm 0.7^{\mathrm{a}}$ & $2.9 \pm 1.5^{\mathrm{b}}$ & $*$ \\
\hline Number of spawn/spawning female & $2.4 \pm 0.4^{\mathrm{a}}$ & $3.6 \pm 0.9^{b}$ & $*$ \\
\hline Number of consecutive maturation per female & $2.5 \pm 0.5^{a}$ & $3.6 \pm 0.8^{b}$ & $*$ \\
\hline Latency period (days) & $10.7 \pm 4.6^{\mathrm{a}}$ & $7.4 \pm 1.8^{\mathrm{b}}$ & $*$ \\
\hline Females that spawned at least once (\%) & $53.8 \pm 27.2^{\mathrm{a}}$ & $77.1 \pm 20.0^{\mathrm{b}}$ & $* *$ \\
\hline
\end{tabular}

Within rows, superscript letters indicate significant differences $(* P<0.05 ; * * P<0.01$; $* * P<0.001$; ns, no significant difference). 
Figure 2 Percentage of cumulative spawns (means $\pm \mathrm{SE}$ ) of L. stylirostris spawners from floc system and earthen pond during a period of 30 days from ablation.

Figure 3 Number of spawns per initial female per month (means \pm SE) of L. stylirostris spawners from floc system and earthen pond during a period of 30 days from ablation.
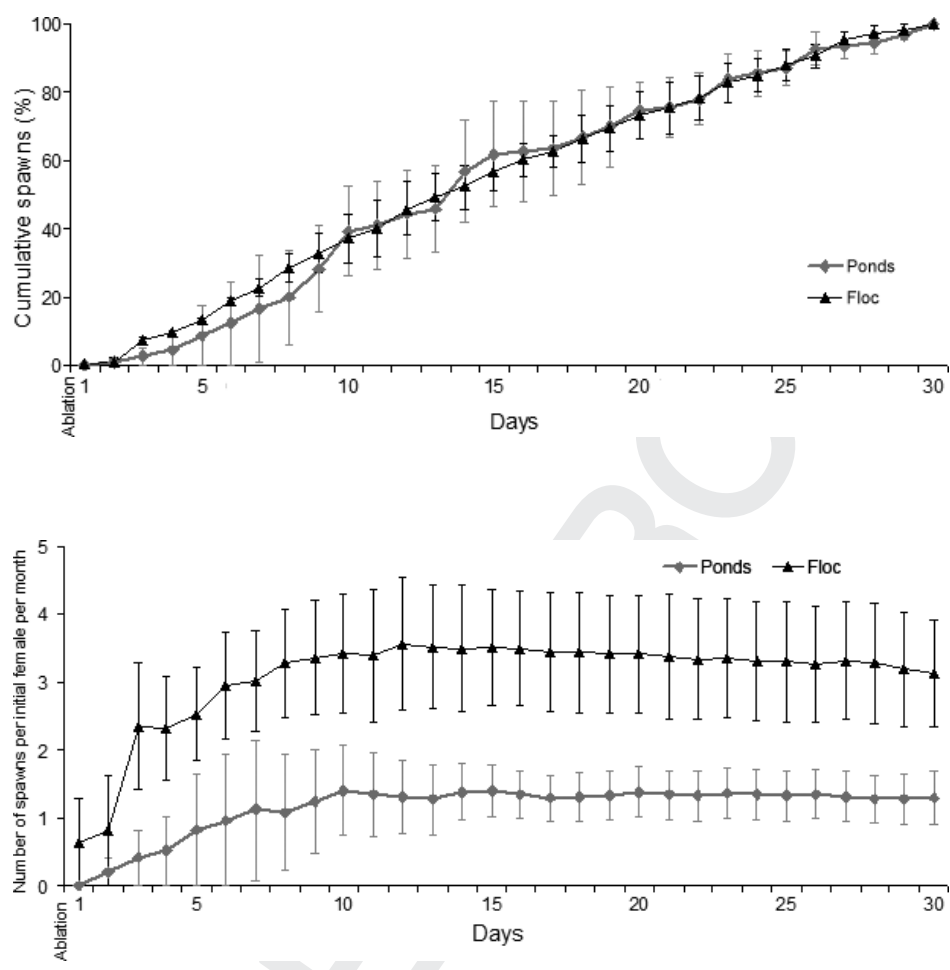

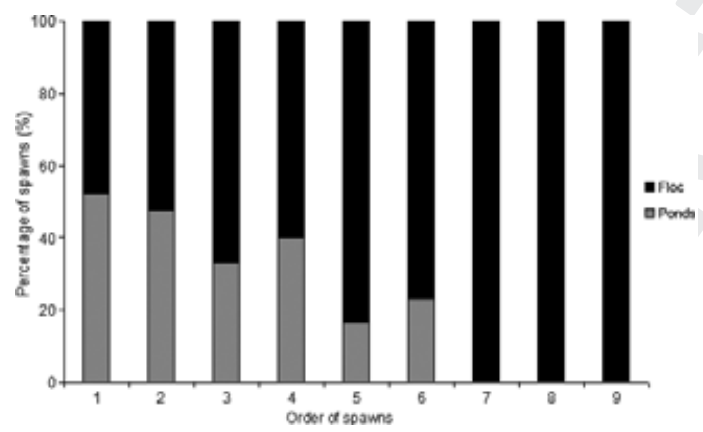

Figure 4 Percentage of spawns (\%) in each spawn order of L. stylirostris spawners from floc system and earthen pond during a period of 30 days from ablation.

or sometimes never spawn, whereas a small percentage is able to spawn several times (Cavalli, Scardua \& Wasielesky 1997; Palacios, Racotta \& APSA 1999a; Ibarra et al. 2007). Hence, the number of spawns is considered as an important criterion to evaluate broodstock performance (Ibarra et al. 2007). High-quality spawners will represent higher amount of spawns per animal, and are less demanding in terms of costs and broodstock maintenance to achieve a target production.

In this study, floc females in terms of number of spawns per ablated female and number of spawns
Table 2 Biochemical composition (means \pm SE based on dry matter) of hepatopancreas and ovary of L. stylirostris spawners from floc system and earthern pond collected during a period of 30 days after ablation

\begin{tabular}{|c|c|c|c|}
\hline & Pond & Floc & $\begin{array}{c}\text { Significance } \\
\text { level }\end{array}$ \\
\hline \multicolumn{4}{|l|}{ Hepatopancreas } \\
\hline $\begin{array}{l}\text { Acylglycerides } \\
\left(\mathrm{mgg}^{-1}\right)\end{array}$ & $63.3 \pm 6.1$ & $64.2 \pm 6.4$ & ns \\
\hline $\begin{array}{l}\text { Cholesterol } \\
\left(\mathrm{mgg}^{-1}\right)\end{array}$ & $12.6 \pm 1.7$ & $14.3 \pm 1.6$ & ns \\
\hline $\begin{array}{l}\text { Total sol. } \\
\text { protein } \\
\left(\mathrm{mgg}^{-1}\right)\end{array}$ & $93.4 \pm 15.2$ & $85.3 \pm 14.8$ & ns \\
\hline AG:TSP & $1.0 \pm 0.4$ & $1.2 \pm 0.3$ & ns \\
\hline AG:C & $4.5 \pm 0.6$ & $4.5 \pm 0.5$ & ns \\
\hline \multicolumn{4}{|l|}{ Ovary } \\
\hline $\begin{array}{l}\text { Acylglycerides } \\
\left(\mathrm{mgg}^{-1}\right)\end{array}$ & $64.2 \pm 3.7^{\mathrm{a}}$ & $42.2 \pm 3.1^{b}$ & $* *$ \\
\hline $\begin{array}{l}\text { Cholesterol } \\
\left(\mathrm{mgg}^{-1}\right)\end{array}$ & $8.1 \pm 0.5$ & $11.6 \pm 3.8$ & ns \\
\hline $\begin{array}{l}\text { Total sol. } \\
\text { protein } \\
\left(\mathrm{mgg}^{-1}\right)\end{array}$ & $111.0 \pm 9.1$ & $97.4 \pm 6.6$ & ns \\
\hline AG:TSP & $0.6 \pm 0.1^{\mathrm{a}}$ & $0.4 \pm 0.04^{b}$ & * \\
\hline AG:C & $8.0 \pm 0.5$ & $6.6 \pm 2.9$ & ns \\
\hline
\end{tabular}

Within rows, superscript letters indicate significant differences $(* P<0.05 ; * * P<0.001 ;$ ns, no significant difference). Hepa- 
per spawning female performed an average of 1.6 and 1.2 times more spawns than pond females, respectively. Females in floc spawned 3.6 times per spawning female, which is much more than observed in wild or domesticated $P$. esculentus (Keys \& Crocos 2006), Farfantepenaeus paulensis (Peixoto, Wasielesky, Martino, Milach, Soares \& Cavalli 2008) F. indicus (Regunathan 2008) and L. stylirostris (Mendoza 1997). The percentage of females that spawned at least once, was $20 \%$ higher in floc females than pond ones (77.1 vs. $53.8 \%)$. It is in agreement with the spawning performance of wild P. monodon (78.2\%) (Menasveta, Piyatiratitivorakul, Rungsurpa, Moree \& Fast 1993). Furthermore, females from floc maturated in an average of 3.6 times, with a maximum of nine consecutive maturations per female compared with 2.5 times, with a maximum of six maturations from pond females. These values are higher than wild and pond-reared P. monodon performances with a maximum of seven and three maturations per female, respectively (Menasveta et al. 1993) and pond-reared L. stylirostris with a maximum of four (Wabete, Chim, Pham, Lemaire \& Massabuau 2006).

Latency period is related to the initial time required for biochemical and physiological changes after eyestalk ablation (Cavalli et al. 1997; Peixoto et al. 2008), and these changes were based on nutrient storage transport from hepatopancreas to ovary for egg development. Eyestalk ablation causes severe hormonal changes, reducing or suppressing moult-inhibiting hormone (MIH) and gonad-inhibiting hormones (GIH) (Sainz-Hernández, Racotta, Dumas \& HernándezLópez 2008). Latency time can vary, as some females are able to develop full ovaries and spawn in 3-5 days, but if moulting occurs soon after eyestalk ablation, the maturation period could extend to 2-3 weeks (Aquacop 1979). In addition, the latency period is an indicator of females with multiple spawning capacities and a criterion to establish the cut-off period of non-spawning females (Palacios, Ibarra \& Racotta 2000; Racotta et al. 2003). In this study, females from floc had a shorter latency period by 3 days compared with pond spawners (7.4 vs. 10.7 days). This is less than 24-40 and

17-33 days reported in wild and pond-reared $L$. vannamei, respectively (Palacios et al. 2000), 10 and 30 days reported in captive and sea-caught $F$. paulensis (Cavalli et al. 1997; Peixoto, Wasielesky,
D‘Incao \& Cavalli 2003; Peixoto, Cavalli, Wasielesky, D‘Incao, Krummenauer \& Milach 2004) and finally 9.4 and 16.8 for wild and pond-reared $P$. monodon (Menasveta et al. 1993). This result is probably related to a better nutritional physiology condition of eyestalk ablated females from floc. The same trend was observed in wild F. paulensis females that started spawning earlier and presented a higher spawning frequency than in ponds conditions (Cavalli et al. 1997). According to Muthu (1983), species such as F. merguiensis, $F$. indicus, L. vannamei and L. stylirostris, generally mature more rapidly (3-4 days) than P. monodon and $F$. aztecus ( 3 weeks).

Mortality rates were high in both treatments with $69 \%$ and $68 \%$ for ponds and floc, respectively. The reason was possibly due to a strong physiological stress resulting from eyestalk ablation followed by multiple spawning rates. Mendoza (1997), evaluating the same species, reported an overall mortality of $49 \%$ in wild and domesticated females, but with less number of spawns per female when compared with our results. Therefore, a high mortality, aside from stress, was closely related to a high number of spawns followed by progressive decrease of reserve levels (Palacios, Perez-Rostro, Ramirez, Ibarra \& Racotta 1999b).

Weight differences observed in our study did not affect the overall result. Menasveta, Sangpradub, Piyatiratitivorakul and Fast (1994) observed that larger P. monodon females (>120 g) underwent more advanced stages of maturation and spawned with greater success than small $(<110 \mathrm{~g})$ spawners. On the other hand, Coman, Arnold, Peixoto, Crocos, Coman and Preston (2006) suggested that broodstock size was not the sole factor affecting the spawning performance of wild and domesticated $P$. monodon. In our study, shrimp weight was in a range of 40-53 g, an adequate size for $L$. stylirostris broodstock (Chamberlain \& Lawrence 1981; Bray, Lawrence \& Lester 1990; Mendoza 1997). Hence, it was assumed that animals were in the same physiological condition. Differences in maturation observed after ablation were due to previous nutritional status in relation to floc or pond conditions. Results in terms of eggs production were similar to wild L. stylirostris (Alfaro, Zúñiga \& Komen 2004), pond-reared (Bray et al. 1990) and followed consecutive years of massive selection performed in Ifremer-COP (Goguenheim et al. 1999) . 


\section{Biochemical analysis}

No significant differences were found in metabolites from $\mathrm{HP}$ and OV, except in AG and AG:TSP ratio of ovary. AG is a readily accessible source of energy that can be used during periods of food shortage (Fraser 1989), and its reduced levels (42.2 vs. $64.2 \mathrm{mg} \mathrm{g}^{-1}$ for floc and ponds, respectively) are related to the large amount of energy required for spawning activity (Palacios, PerezRostro, Ramirez, Ibarra \& Racotta 1999b). Successive spawns following a decrease in nutrient storage induced a progressive decrease of spawning rates, well explained as reproductive exhaustion (for reviews, see Lumare 1979; Palacios et al. 1999b).

According to Anger (2001) AG:TSP is an energetic ratio that evidence AG storage when higher values present differences between treatments. On the other hand, AG:C is a nutritional ratio that could indicate nutritional deficiency in shrimp when values are quite close to zero (Anger 2001). These ratios as a condition index are largely affected by energy availability (Mourente \& Rodríguez 1997). In the present study, AG:TSP measured in ovary indicated a significantly better response in females from pond than those from floc. Similar metabolites trend was obtained in F. paulensis with or without sand substrate in maturation tanks (Nakayama, Peixoto, Bianchini, Robaldo \& Cavalli 2008), however, with decrease in another source of energy (glucose).

AG, cholesterol and TSP content can just give a preliminary information on nutritional status of shrimp, but nutritional indicators such as fatty acids profile and different classes of lipids (polar and neutral lipids) are more indicative. These nutrients are strictly related to the reproductive performance (Teshima \& Kanazawa 1983; Teshima, Kanazawa, Kushio \& Horinouchi 1988). Cahu, Guillaume, Stéphan and Chim (1994) showed that conditions with low dietary phospholipids concentration associated with a low HUFA level induces a decrease in the spawning rate of $P$. vannamei, as female has limited ability for their biosynthesis. On the other hand, the knowledge on specific nutrient requirement for successful reproductive performance is still limited, and a better spawning income could not be attributed to any single nutrient (Regunathan 2008). Meanwhile, it could be presumed that a deficit in essential aminoacids, fatty acids (mainly represented by
PUFAs and HUFAs) or vitamins can contribute to decrease on embryogenesis of $M$. rosenbergii (Clarke, Brown \& Holmes 1990), vitellogenesis of L. vannamei (Wouters, Piguave, Bastidas, Calderón \& Sorgeloos 2001b) and affect the overall reproductive performance (Teshima et al. 1988). The benefit of floc is difficult to clarify due to the lack of precision of its composition, as well as the variation in the amount of particulate biomass ingested, apart from nutrients derived from pelleted commercial feed . Furthermore, more research efforts are needed to evaluate different floc protocols and food management (with or without fresh food in a short-term prior to the reproduction season) with an aim to improve L. stylirostris reproduction fed only on dry feed.

\section{Floc vs. pond-reared cultured systems}

The better spawning performance of females from floc could be explained from a nutritional and 'susceptibility to stress' points of view, where conditions differed from pond to floc systems (Table 3). Besides the stocking density, variations in abiotic factors, such as $\mathrm{pH}$ and dissolved oxygen, caused by phytoplankton blooms could deplete broodstock health in ponds (Wabete et al. 2006). Also, temperature fluctuations in ponds due to water stratification and water exchange could create stress on animals during daytime. Moreover, limited natural productivity in ponds could not represent a

Table 3 Summary of factors that could influence the broodstock health and nutrition in general earthen ponds and floc system, and its respective score

\begin{tabular}{lll}
\hline & Pond & Floc \\
\hline Abiotic and crowding & & \\
Temperature, DO and pH fluctuations & $* * *$ & $*$ \\
Ammonia control & $*$ & $* *$ \\
Salinity variance & $*$ & $* *$ \\
Crowding & $*$ & $* * *$ \\
Nutritional factors & & \\
'Native protein' and essentials aminoacids ${ }^{1}$ & $*$ & $* * *$ \\
Phospholipids & $*$ & $* *(?)$ \\
Lipids, PUFA's and HUFA's ${ }^{2}$ & $*$ & $* * *$ \\
Cholesterol & $*$ & ${ }^{* *}(?)$ \\
Vitamins & $*$ & ${ }^{* *}(?)$ \\
'Unknown growth factor' & $*$ & ${ }^{* * *}(?)$ \\
\hline
\end{tabular}

Scale are given by $*, * *$ and $* * *$ that represent low, intermediate and high levels or effects; DO, dissolved oxygen; ${ }^{1} \mathrm{Ju}$ et al. (2008); ${ }^{2}$ Azim and Little (2008), Crab et al. (2010) and Ekasari et al. (2010); ?, unclear levels. 
significant portion of essentials nutrients for shrimp, in particular, at high biomass.

In contrast, floc conditions present a regular availability of food in a form of highly diverse 'native protein' that include bacteria (Ballester et al. 2010), microalgae, protozoa, nematodes (Azim \& Little 2008), copepods and rotifers (Decamp, Conquest, Forster \& Tacon 2002; Ray et al. 2010). The concept of 'native protein' is related to protein source without previous treatment mainly including live food. Bacteria play an essential role in this equilibrium and re-ingestion of particulate organic matter and faeces (coprophagia) left by shrimp results in a form of constant food supply. The colonization of shrimp gut by bacteria is another benefit with a possible probiotic effect. Bacteria biomass intake could be responsible for better reproductive performance under floc conditions. Moreover, floc is a source of free aminoacids $(\mathrm{Ju}$, Forster, Conquest, Dominy, Kuo \& Horgen 2008), total lipid (Azim \& Little 2008) and essential fatty acids (Crab, Chielens, Wille, Bossier \& Verstraete 2010; Ekasari, Crab \& Verstraete 2010). It is well known that these nutrients significantly affect the reproductive performance in peneid broodstock (Paibulkichakul, Piyatiratitivorakul, Sorgeloos \& Menasveta 2008), and could also influence the initial gonad tissue formation at juvenile stages.

Abiotic factors are better controlled by tank shading and low or zero water renewal (Crab, Kochva, Verstraete \& Avnimelech 2009) providing a more stable medium for broodstock (Wabete et al. 2006). Heterotrophic bacteria might control phytoplankton blooms as well as reduce pH-dissolved oxygen fluctuations, typically presented in ponds. Moreover, nitrogen compounds such as ammonia is constantly recycled and uptaken by heterotrophic bacteria (Avnimelech 1999). Although male quality was not the aim of this study, it is important to note that male from pond presented more frequent melanized spermatophore than floc males, even though undamaged spermatophores were used. This trend seems to be associated with dissolved oxygen-temperature fluctuations that could deplete male health in ponds (Sánchez, Pascual, Sánchez, Vargas-Albores, Moullac \& Rosas 2001).

\section{Conclusion}

Floc is a difficult concept to explain, because it is a complex system with continuous physical, chemi- cal and biological interactions. From a nutritional point of view, there is no clear evidence as to how floc participates in the nutritional requirements. Incidence on weight gain was shown in the past (Burford et al. 2004; Wasielesky et al. 2006), unfortunately no specific nutrient has been detected. One postulation is related to 'growth factor' similar to that found in squid (Cruz-Ricque, Guillaume \& Cuzon 1987; Guillaume, Cruz-Ricque, Cuzon, Wormhoudt \& Revol 1989). Nevertheless, one could emphasize the fact that floc is a source of 'native proteins', fatty acids preserved from oxidation and vitamins (Crab et al. 2010). During the drying processing, the floc was produced in bioreactors and included in compounded feeds, and the nutritional characteristics could be affected by high temperatures.

This study contributes to a better understanding of the role of floc on spawning performance of shrimp. Floc females had higher spawn activity in a shorter period of time compared with pond females. The spawners from floc require less time to start spawning as see by the shorter latency period. Spawning performance is also attributed to a better nutritional status and medium conditions experienced by floc females in grow-out phase (Table 3). Ovary AG content was lower in floc females than pond ones due to a higher need of energy for multiple spawns and consequently, reproductive exhaustion experienced. There is a need for further research to achieve a better understanding of the role of floc in broodstock nutrition.

\section{Acknowledgments}

The authors thank CAPES-Brazil for the PhD grant to the primary author (grant 4814061). Advice and technical assistance on biochemical analysis from Ariadna Sanches and Vianey Sosa are greatly appreciated. Thanks are also due to Shital Swarup for critical reading of the manuscript, and to anonymous referees for their valuable suggestions on this manuscript.

\section{References}

Alfaro J., Zúñiga G. \& Komen J. (2004) Induction of ovarian maturation and spawning by combined treatment of serotonin and a dopamine antagonist, spiperone in Litopenaeus stylirostris and Litopenaeus vannamei. Aquaculture 236, 511-522. 
Anger K. (2001) The Biology of Decapods Crustacean Larvae, 1st edn. A. A. Balkema publishers, Rotterdam, Netherlands.

Aquacop (1975) Maturation and spawning in captivity of penaeid shrimps Penaeus merguiensis de Man, P. japonicus Bate, P. aztecus Ives, Metapenaeus ensis de Haan and P. semisulcatus de Haan. In: Proceedings of the 6th Annual Meeting of World Mariculture Society, 27- 31 January 1975, (ed. by ???? ????), pp. 123-132. ?????, Seattle, WA.

Aquacop (1979) Penaeid reared broodstock: closing the life cycle of $P$. monodon, $P$. stylirostris and P. vannamei. Proceeding of World Mariculture Society 10, 425-452.

Arce S., Moss S.M. \& Argue B.J. (1999) Artificial insemination and spawning of pacific white shrimp Litopenaeus vannamei: implications for a selective breeding program. In: Spawning and Maturation of Aquaculture Species. UJNR Aquaculture Techcnical report.Vol 28 (ed. by???? ????), pp. 5-8. ?????, ???????.

Avnimelech Y. (1999) Carbon and nitrogen ratio as a control element in aquaculture systems. Aquaculture 176, 227-235.

Avnimelech Y. (2009) Biofloc Technology - A Practical Guide Book. The World. Aquaculture Society, Baton Rouge, Louisiana, EUA.

Azim M.E. \& Little D.C. (2008) The biofloc technology (BFT) in indoor tanks: water quality, biofloc composition, and growth and welfare of Nile tilapia (Oreochromis niloticus). Aquaculture 283, 29-35.

Ballester E.L.C., Abreu P.C., Cavalli R.O., Emerenciano M., Abreu L. \& Wasielesky W. (2010) Effect of practical diets with different protein levels on the performance of Farfantepenaeus paulensis juveniles nursed in a zero exchange suspended microbial flocs intensive system. Aquaculture Nutrition 16, 163-172.

Bianchi M. \& Bianchi A. (1982) Evolution à court terme des effectifs et de l'activité des communautés bactériennes dans des ècosystèmes d'aquaculture. In: Deuxième Colloque de Microbiologie Marine, Marseille, 1981, CNEXO, Actes Colloq. 13, (ed. by ???? ????), pp. 61-70. ?????, ??????.

Bradford M.M. (1974) A refined method of microgram quantities of protein utilizing the principle of proteindye binding. Analytical Biochemistry 72, 248-253.

Bray W.A., Lawrence A.L. \& Lester L.J. (1990) Reproduction of Eyestalk- blated Penaeus stylirostris Fed Various Levels of Total Dietary Lipid. Journal of the World Aquaculture Society 21, 41-52.

Burford M.A., Thompson P.J., McIntosh R.P., Bauman R. H. \& Pearson D.C. (2004) The contribution of flocculated material to shrimp (Litopenaeus vannamei) nutrition in a high-intensity, zero-exchange system. Aquaculture 232, 525-537.

Cahu C., Guillaume J.C., Stéphan G. \& Chim L. (1994) Influence of phospholipid and highly unsaturated fatty acids on spawning rate and egg and tissue composition in Penaeus vannamei fed semi-purified diets. Aquaculture 126, 159-170.

Cavalli R.O., Scardua M.P. \& Wasielesky W.J. (1997) Reproductive performance of different sized wild and pond- reared Penaeus paulensis females. Journal of the World Aquaculture Society 28, 260-267.

Chamberlain G.W. \& Lawrence A.L. (1981) Maturation, reproduction, and growth of Penaeus vannamei and $P$. stylirostris fed natural diets. Journal of the World Aquaculture Society 12, 207-224.

Clarke A., Brown J.H. \& Holmes L.J. (1990) The biochemical composition of eggs from Macrobrachium rosenbergii in relation to embryonic development. Comparative Biochemistry and Physiology 96, 505-511.

Cole J.J. (1982) Interactions between bacteria and algae in aquatic ecosystems. Annual Review of Ecology and Systematics 13, 291-314.

Coman G.J., Arnold S.J., Peixoto S., Crocos P.J., Coman F.E. \& Preston N.P. (2006) Reproductive performance of reciprocally crossed wild-caught and tank-reared Penaeus monodon broodstock. Aquaculture 252, 372 384.

Coman G.J., Arnold S.J., Callaghan T.R. \& Preston N.P. (2007) Effect of two maturation diet combinations on reproductive performance of domesticated Penaeus monodon. Aquaculture 263, 75-83.

Crab R., Kochva M., Verstraete W. \& Avnimelech Y. (2009) Bio-flocs technology application in over-wintering of tilapia. Aquacultural Engineering 40, 105-112.

Crab R., Chielens B., Wille M., Bossier P. \& Verstraete W. (2010) The effect of different carbon sources on the nutritional value of bioflocs, a feed for Macrobrachium rosenbergii postlarvae. Aquaculture Research 41, 559567.

Cruz-Ricque L.E., Guillaume J. \& Cuzon G. (1987) Squid protein effect on growth of four penaeid shrimp. Journal of the World Aquaculture Society 18, 209-217.

Cuzon G., Lawrence A., Gaxiola G., Rosas C. \& Guillaume J. (2004) Nutrition of Litopenaeus vannamei reared in tanks or in ponds. Aquaculture 235, 513-551.

De Schryver P., Crab R., Defoirdt T., Boon N. \& Verstraete W. (2008) The basics of bioflocs technology: the added value for aquaculture. Aquaculture 277, 125-137.

Decamp O., Conquest L., Forster I. \& Tacon A.G.J. (2002) The nutrition and feeding of marine shrimp within zero-water exchange aquaculture production system: role of Eukaryotic microorganisms. In: Microbial Approaches to Aquatic Nutrition within Environmentally Sound Aquaculture Production Systems, (ed by C.S. Lee \& ???? O’Bryen), pp. 79-86. World Aquaculture Society, Baton Rouge, USA.

Ekasari J., Crab R. \& Verstraete W. (2010) Primary nutritional content of bio-flocs cultured with different organic carbon sources and salinity. Hayati Journal of Biosciences 17, 125-130. 
Emerenciano M.G.C., Wasielesky W., Soares R.B., Ballester E.C., Cavalli R.O. \& Izeppi E.M. (2007) Crescimento e sobrevivência do camarão-rosa Farfantepenaeus paulensis na fase de berçário em meio heterotrófico. Acta Scientiarum. Biological Sciences 29, 1-7.

Emerenciano M., Cuzon G. \& Gaxiola G. (2011) Tecnología de biofloc (BFT): perspectivas para la Península de Yucatán. In: Recursos Costeros del Sureste: tendencias actuales en investigación y estado del arte (ed. by RECORECOS), cap. 42, in press. pp. ????-????. ?????????, ???????.

Iraser A.J. (1989) Triacylglycerol content as a condition index for fish, bivalve and crustacean larvae. Canadian Journal of Fisheries and Aquatic Science 46, 1868-1873.

Garen P. \& Aquacop (1993) Nuevos resultados en la cría intensiva de camarón Penaeus vannamei y P. stylirostris. In: Memorias del I Congresso Ecuatoriano de Acuicultura, (ed. by J.V. Calderón \& V.C. Sandoval), pp. 137-145. Guayaquil, 18-23 Octubre 1992. Escuela Superior Politécnica del Litoral, Guayaquil.

Gitterle T., Salte R., Gjerde B., Cock J., Johansen H., Salazar M., Lozano C. \& Rye M. (2005) Genetic (co) variation in resistance to White Spot Syndrome Virus (WSSV) and harvest weight in Penaeus (Litopenaeus) vannamei. Aquaculture 246, 139-149.

Goguenheim J., Rouxel C., Blanvillain C. \& De Gregorio C. \& Aquacop (1999) Use of refrigerated sperm of Penaeus stylirostris: insemination and fertilization results. In: Book of Abstracts of International Congress of Cryobiology, 12-15 July 1999, (ed. by ???? ?????), pp. 256-????. ?????????, Marseille, France.

Goyard E., Patrois J., Peignon J., Vanaa V., Dufour R., Viallon J. \& Bedier E. (2002) Selection for better growth of Penaeus stylirostris in Tahiti and New Caledonia. Aquaculture 204, 461-468.

Guillaume E., Cruz-Ricque E., Cuzon G., Wormhoudt A. \& Revol A. (1989) Growth factors in penaeid shrimp feeding, Advances in Tropical Aquaculture, Actes de Colloque vol. 9, pp. 327-338. AQUACOP, IFREMER, Tahiti.

Hargreaves J.A. (2006) Photosynthetic suspended-growth systems in aquaculture. Aquacultural Engineering 34, 344-363.

Ibarra A.M., Racotta I.S., Arcos F.G. \& Palacios E. (2007) Progress on the genetics of reproductive performance in penaeid shrimp. Aquaculture 268, 23-43.

Ju Z.Y., Forster I., Conquest L., Dominy W., Kuo W.C. \& Horgen F.D. (2008) Determination of microbial community structures of shrimp floc cultures by biomarkers and analysis of floc amino acid profiles. Aquaculture Research 39, 118-133.

Keys S.J. \& Crocos P.J. (2006) Domestication, growth and reproductive performance of wild, pond and tankreared brown tiger shrimp Penaeus esculentus. Aquaculture 257, 232-240.

Lumare F. (1979) Reproduction of Penaeus kerathurus using eyestalk ablation. Aquaculture 18, 203-214.
Menasveta P., Piyatiratitivorakul S., Rungsurpa S., Moree N. \& Fast A.W. (1993) Gonadal maturation and reproductive performance of giant prawn (Penaeus monodon Fabricius) from the Andaman Sea and pond-reared sources in Thailand. Aquaculture 116, 191-198.

Menasveta P.S., Sangpradub S., Piyatiratitivorakul S. \& Fast A.W. (1994) Effects of broodstock size and source on ovarian maturation and spawning of giant tiger prawn Penaeus monodon Fabricius from the Gulf of Thailand. Journal of the World Aquaculture Society 25 , 41-49.

Mendoza R. (1997) Penaeus stylirostris nauplii production from wild, cultivated and mixed populations. Journal of Applied Aquaculture 7, 41-50.

Mourente G. \& Rodríguez A. (1997) Effects of salinity and dietary DHA (22:6n3) content on lipid composition and performance of Penaeus kerthurus postlarvae. Marine Biology 128, 289-298.

Muthu M.S. (1983) Penaeid broodstock development and management. In: National Symposium on Shrimp Seed Production and Hatchery Management, 21-22 January 1983, (ed. by???? ?????), pp. ????-????. ?????????, Cochin.

Nakayama C.L., Peixoto S., Bianchini A., Robaldo R. \& Cavalli R.O. (2008) Performance of Farfantepenaeus paulensis (Pérez-Farfante, 1967) broodstock in tanks with sand and hard substrate. Aquaculture Research 39 , 398-405.

Paibulkichakul C., Piyatiratitivorakul S., Sorgeloos P. \& Menasveta P. (2008) Improved maturation of pondreared, black tiger shrimp (Penaeus monodon) using fish oil and astaxanthin feed supplements. Aquaculture 282, 83-88.

Palacios E., Ibarra A.M., Ramirez J.R., Portillo G. \& Racotta I.L. (1998) Biochemical composition of eggs and nauplii on white pacific shrimp Penaeus vannamei (Boone) in relation to the physiological condition of spawners in the comercial hatchery. Aquaculture Research 29, 183-189.

Palacios E., Racotta I.S. \& APSA (1999a) Spawning frequency analysis of wild and pond-reared shrimp Penaeus vannamei broodstock under large-scale hatchery conditions. Journal of the World Aquaculture Society 30 , 180-191.

Palacios E., Perez-Rostro C.I., Ramirez J.L., Ibarra A.M. \& Racotta I.S. (1999b) Reproductive exhaustion in shrimp (Penaeus vannamei) reflected in larval biochemical composition, survival and growth. Aquaculture 171, 309-321.

Palacios E., Ibarra A.M. \& Racotta I.S. (2000) Tissue biochemical composition in relation to multiple spawning in wild and pond-reared Penaeus vannamei broodstock, Aquaculture 185, 353-371.

Peixoto S., Wasielesky W., D‘ncao F. \& Cavalli R.O. (2003) Reproductive performance of similarly-sized wild and captive Farfantepenaeus paulensis. Journal of the World Aquaculture Society 34, 50-56. 
Peixoto S., Cavalli R.O., Wasielesky W., D‘Incao F., Krummenauer D. \& Milach A. (2004) Effects of age and size on reproductive performance of captive Farfantepenaeus paulensis broodstock. Aquaculture 238, 173-182.

Peixoto S., Wasielesky W., Martino R., Milach A., Soares R. \& Cavalli R.O. (2008) Comparison of reproductive output, offspring quality, ovarian histology and fatty acid composition between similarly-sized wild and domesticated Farfantepenaeus paulensis. Aquaculture 285, 201-206.

Racotta I.S., Palacios E. \& Ibarra A.M. (2003) Shrimp larval quality in relation to broodstock condition. Aquaculture 227, 107-130.

Ray A.J., Seaborn G., Leffler J.W., Wilde S.B., Lawson A. \& Browdy C.L. (2010) Characterization of microbial communities in minimal-exchange, intensive aquaculture systems and the effects of suspended solids management. Aquaculture 310, 130-138.

Regunathan C. (2008) Variation in reproductive performance and egg quality between wild and pond-reared indian white shrimp, Fenneropenaeus indicus, broodstock. Journal of Applied Aquaculture 20, 1-17.

Rosenberry B. (2010) Controlling $\mathrm{pH}$ in biofloc ponds. The shrimp news international. http://www.shrimpnews. com/FreeReportsFolder/phContronBioflocPonds.html.

Sánchez A., Pascual C., Sánchez A., Vargas-Albores F., Moullac G.L. \& Rosas C. (2001) Hemolymph metabolic variables and immune response in Litopenaeus setiferus adult males: the effect of acclimation. Aquaculture $\mathbf{1 9 8}$, $13-28$.

Sainz-Hernández J.C., Racotta I.S., Dumas S. \& Hernández-López J. (2008) Effect of unilateral and bilateral eyestalk ablation in Litopenaeus vannamei male and female on several metabolic and immunologic variables. Aquaculture 283, 188-19.

Samocha T.M., Patnaik S., Speed M., Ali A.M., Burger J. M., Almeida R.V., Ayub Z., Harisanto M., Horowitz A. \& Brock D.L. (2007) Use of molasses as carbon source in limited discharge nursery and grow-out systems for Litopenaeus vannamei. Aquacultural Engineering 36, 184 -191 .

Sohier L. (1986) Microbiologie appliquée à l'aquaculture marine intensive. pp. 119. Thèse Doctorat d'Etat, Université Aix-Marseille II ??????
Sohier L. \& Bianchi M. (1985) Development of a heterotrophic bacterial community within a closed prawn aquaculture system. Microbial Ecology 11, 353-370.

Sokal R. \& Rohlf J. (1995) Biometry, the Principles and Practice of Statistics in Biological Research. W H Freeman, New York.

Taw N. (2010) Biofloc technology expanding at white shrimp farms. Global Advocate 10, 20-22.

Teshima S. \& Kanazawa A. (1983) Variation in lipid composition during the ovarian maturation of the prawn. Bulletin of the Japanese Society of Scientific Fisheries 49, 957-962.

Teshima S.I., Kanazawa A., Kushio S. \& Horinouchi K. (1988) Lipid metabolism in destalked prawn Penaeus japonicus: induced maturation and accumulation of lipids in the ovaries. Nippon Suisan Gakkaishi 54, 11151122.

Wabete N., Chim L., Pham D., Lemaire P. \& Massabuau J.C. (2006) A soft technology to improve survival and reproductive performance of Litopenaeus stylirostris by counterbalancing physiological disturbances associated with handling stress, Aquaculture 260, 181-193.

Wasielesky W., Atwood H., Stokes A. \& Browdy C.L. (2006) Effect of natural production in a zero exchange suspended microbial floc-based super-intensive culture system for white shrimp Litopenaeus vannamei. Aquaculture 258, 396-403.

Williams P.J. (2000) Heterotrophic bacteria and the dynamics of dissolved organic material. In: Microbial Ecology of the Oceans, (ed. by D.L. Kirchman), pp. 153200. Wiley-Liss, ?????

Wouters R., Lavens P., Nieto J. \& Sorgeloos P. (2001a) Penaeid shrimp broodstock nutrition: an updated review on research and development. Aquaculture 202, $1-21$.

Wouters R., Piguave X., Bastidas L., Calderón J. \& Sorgeloos P. (2001b) Ovarian maturation and haemolymphatic vitellogenin concentration of Pacific white shrimp Litopenaeus vannamei (Boone) fed increasing levels of total dietary lipids and HUFA. Aquaculture Research 32, 573-582.

Zar J.H. (1984) Biostatistical Analysis, 2nd edn. Prentice Hall, Englewood Cliffs, NJ. 